\title{
Research on the Preference of OECD Climate Aid Donors-Based on OECD Climate Aid Funds Data from 2000 to 2017
}

\author{
Jing ZHOU * Yubing SHANG and Rong KANG \\ Northwest University, Xi'an, Shaanxi, China; 1783646744@qq.com; 732225257@qq.com; 1057816418@qq.com \\ * Correspondence: 1783646744@qq. com
}

\begin{abstract}
When climate change affects countries around the world, one of the most important issues in the negotiations under the United Nations Framework Convention on Climate change is the flow of funds to deal with climate change. However, it can be found that there are few studies on the preference of the climate-aid funds. as a result, based on the climate aid funds data of OECD donors from 2000 to 2017, this paper analyzes the preferences of donor countries in providing climate aid funds from seven points of view, and explores the reasonableness of preferences. The results show that the most preferred countries in the donor countries are India. The most preferred regions are Asia, the most preferred income groups are low-and middle-income countries, the most preferred industries are transport and storage, the main purpose of climate aid funds is to mitigate climate change. In addition, the preference of climate aid funds for countries and uses is not reasonable to a certain extent. In the current economic environment, donor countries should invest more climate aid funds in countries with poor ability to combat climate change, balance the proportion of climate funds in mitigation and adaptation, and increase donations to climate adaptation.
\end{abstract}

Keywords: OECD; climate aid funds; donor preferences; reasonableness

JEL Classification: F21; F35

\section{Introduction}

There is no doubt that climate is an important part of the ecological environment and an important guarantee for sustainable development. The development of human beings and the production of various economic activities cannot be separated from atmospheric resources, climate change will have an important impact on the ecosystem and human society. Since the 20th century, many scientific studies have shown that the global climate is changing dramatically, which has never happened in history (Li Sheng, 2012 / 50). In early November 2014, the United Nations Intergovernmental Panel on Climate change (IPCC) released the IPCC Fifth Assessment report in Copenhagen. The report It is pointed out that since 1950s, many observed changes have been unprecedented in decades or even thousands of years, mainly as follows: the atmosphere and ocean have warmed, the amount of snow and ice is decreasing, the sea level is rising, and the concentration of carbon dioxide in the atmosphere has reached its highest level in the past 800000 years. According to the World Meteorological Organization, the global average surface temperature in 2018 is about $14.68^{\circ} \mathrm{C}$, nearly $1{ }^{\circ} \mathrm{C}$ higher than the pre-industrial baseline. It is the fourth hot year since the temperature record, and there have been 20 hottest years in history in the past 22 years. IPCC released a report on 8 October 2018, which pointed that If climate warming continues at its current rate, global temperatures are expected to rise by 1.5 degrees Celsius between 2030 and 2052 compared with pre-industrial levels.

Looking at the performance of these climate change, we can make it clear that global warming has become a reality. This fact will also affect the natural ecosystem and social and economic activities, such as crop production reduction, frequent natural disasters, economic downturn and a series of problems, and even affect human health and human living environment. To this end, governments have now addressed climate change as an important issue and have taken various measures to deal with climate change (Li Sheng, 2012 / 54 / 57). From 1988, the United Nations Environment Programme (UNEP) and 
the World Meteorological Organization (WMO) jointly promoted the establishment of the United Nations Intergovernmental Committee on Climate change (IPCC) to the birth of the United Nations Framework Convention on Climate change (UNFCCC) in 1992, the adoption of the Kyoto Protocol in 1997, and the climate change conference in Copenhagen in 2009, the international community is constantly taking action to combat climate change (Global Climate Governance and China's Strategic Choice, Li Sheng, 2012). After years of exploration and development, under the joint efforts of the whole world, the United Nations Organization has constructed a fair and reasonable international climate system, established the principles for solving climate problems, formulated a scientific and authoritative assessment report and made a series of structural and institutional arrangements around climate change (Chen, 2012).

When countries begin negotiations under the United Nations Framework Convention on Climate change (UNFCCC), the benefit of different countries is the core focus of the negotiations, one of which is the financing of climate change. At the 2009 Climate change Conference in Copenhagen, developed countries pledged to provide $\$ 100$ billion a year to developing countries to help countries reduce greenhouse gas emissions by 2020. That is called the Green Climate Fund. Developed countries are expected to contribute $\$ 30$ billion between 2010 and 2012, as required by the Copenhagen and Cancun agreements to help the most vulnerable developed countries, such as the least developed countries, small island developing States and African countries, carry out adaptation projects. In addition, long-term funds of $\$ 100$ billion per year should be provided between 2013 and 2020 to help developing countries deal with climate change. On November 30, 2015, the 21st Conference of the parties to the United Nations Framework Convention on Climate change was held in Paris, which led to the Paris Agreement after two weeks of difficult negotiations. Although the agreement has made a significant contribution to climate change mitigation and adaptation, there are still many problems that have not yet been solved. The core question is how developed countries share the money to deal with climate change, that is, who will pay for it, how much, to whom and where will it be spent to really achieve the goal of climate aid. These key issues have not yet been resolved in the Paris Agreement. Therefore, the implementation and use of $\$ 100$ billion is still difficult.

\section{Methodology}

OECD has been trying to count climate-related development funds since 1998, and has formed a complete set of statistical principles and methods. The statistical results presented in this database can show the scale, structure and characteristics of this kind of capital flow in all donor countries of OECD, and have become the basic data for the study of this kind of international capital flow. This paper uses the relevant data of recipient countries to analyze, the available data is 2000-2017 data, so this paper will use 2000-2017 climate aid funds data from seven angles to analyze their preferences.

Generally speaking, this paper will focus on the following two parts to carry out the study of climate aid funds preference. The first part will use the OECD 2000- 2017 funds data for climate aid, through an analysis from seven points of view, including recipients (countries), recipient regions, recipient income groups, recipient industries, climate change targets, financial instruments used and the use of funds to explore the donation preferences of OECD donors. The second part will analyze the reasonableness of climate finance preference from the countries and industries preferred by climate aid donors.

\section{Results}

Based on the climate aid funds data of OECD donors in 2000-2017, this paper will explore the donation preferences of OECD donors in seven points of view by analyzing the climate aid funds provided by all donor countries as following. 


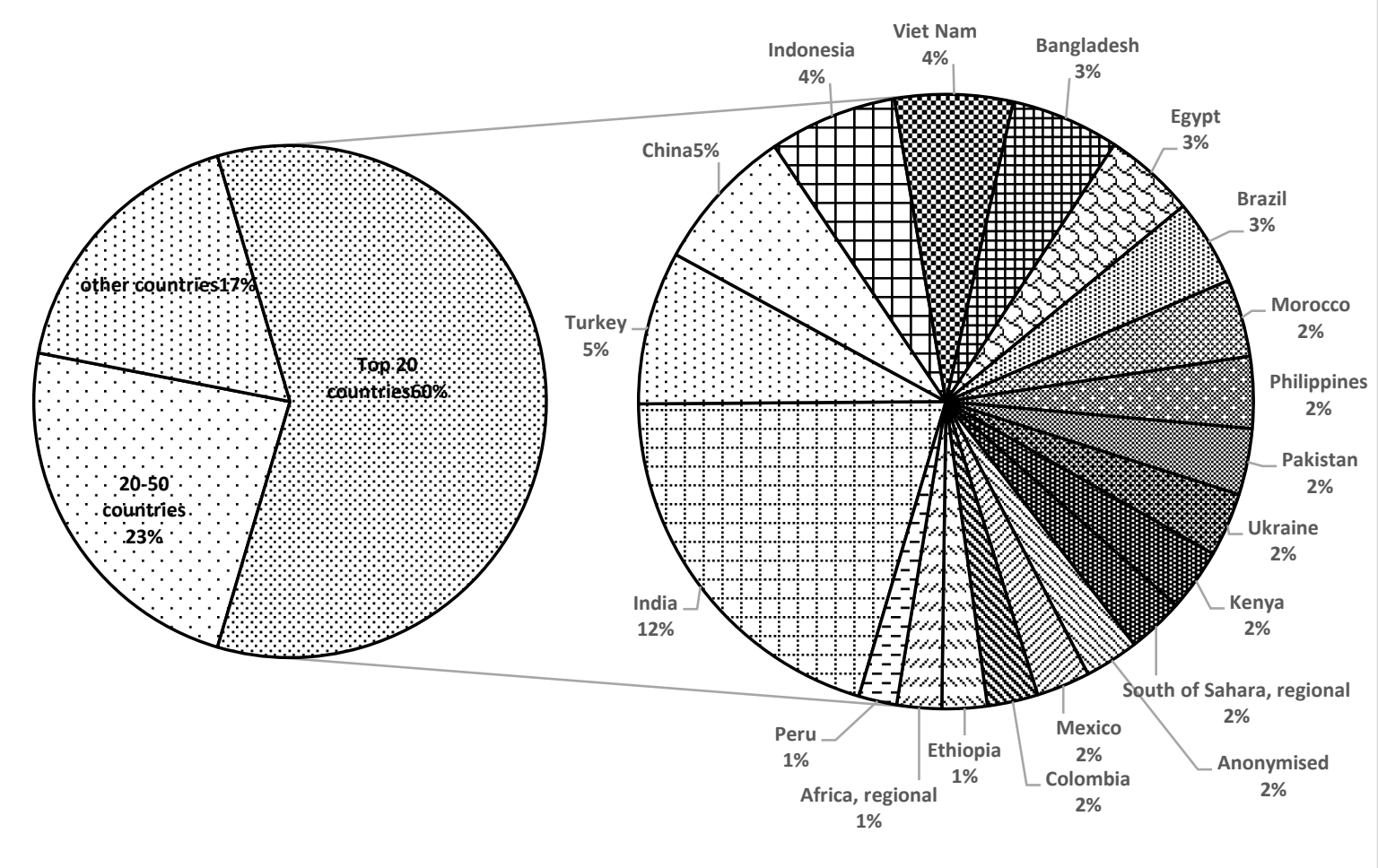

Figure 1. Recipients of climate aid funds, 2000-2017.

As can be seen from the left half of figure 1, donors are significantly preferred in providing climate aid to recipient countries, with the top 20 receiving climate aid fund accounting for 60 percent of the total climate aid fund in 2000-2017, proving that most of the donor countries donated to the top 20 countries, while the right half of figure 1 shows the top 20 countries receiving the most donations. As can be seen from the figure 1, even in the top 20 countries, there is a clear preference, that is, only 5 countries of the top 20 countries in 2000-2017 received more than 3 percent of climate aid funds (excluding 3 percent). They are India (12\%), Turkey (5\%), China (5\%), Indonesia (4\%) and Vietnam $(4 \%)$. India is no doubt the preferred country for donors. In general, donors have a recipient preference for climate aid funds, the most preferred are India, followed by Turkey, China, Indonesia and Vietnam.



Figure 2. Regions of the recipient of the climate aid funds, 2000-2017.

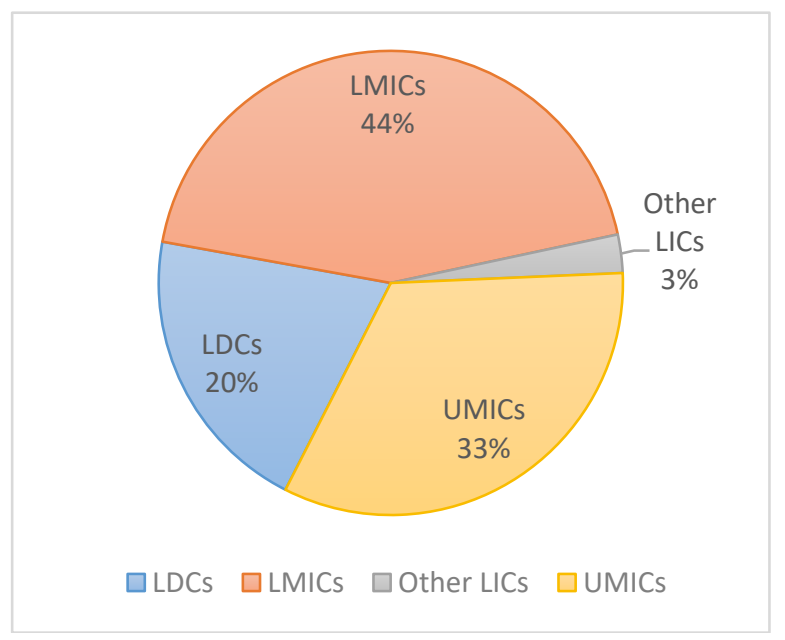

Figure 3. Income groups of the recipients of the climate aid funds, 2000-2017. 
As can be seen from figure 2, donor countries in 2000-2017 have a clear preference for recipient regions in providing climate aid funds, with Asia receiving 46 percent of the total climate aid funds, followed by Africa, the Americas, Europe and Oceania, which accounted for 27 percent, 16 percent, 10 percent and 1 percent of the total climate aid, respectively. So Asia is the preferred region for donors, and Asia received 3 percent more climate aid funds in 2000-2017 than America and Africa combined. In general, donors have a regional preference for climate aid funds, with preference for Asia, Africa and America.

As can be seen from figure 3, donor countries have a clear preference for income groups of the recipients in providing climate aid funds in 2000-2017. Low-income countries and regions received 44 percent of the total climate aid funds, followed by middle-and high-income countries and regions and least developed countries and regions, receiving 33 percent and 20 percent of climate aid funds, respectively. While other low-income countries accounted for the least, with only 3 percent. Therefore, from the point of view of the amount of funds, low-and middle-income countries and regions are the most preferred income groups in donor countries, followed by middle-and high-income countries and regions. In general, donor countries have a preference for the income groups of the recipients in the provision of climate-aid funds, with a preference for middle-and low-income countries, middle-and high-income countries and regions and the least developed countries and regions.

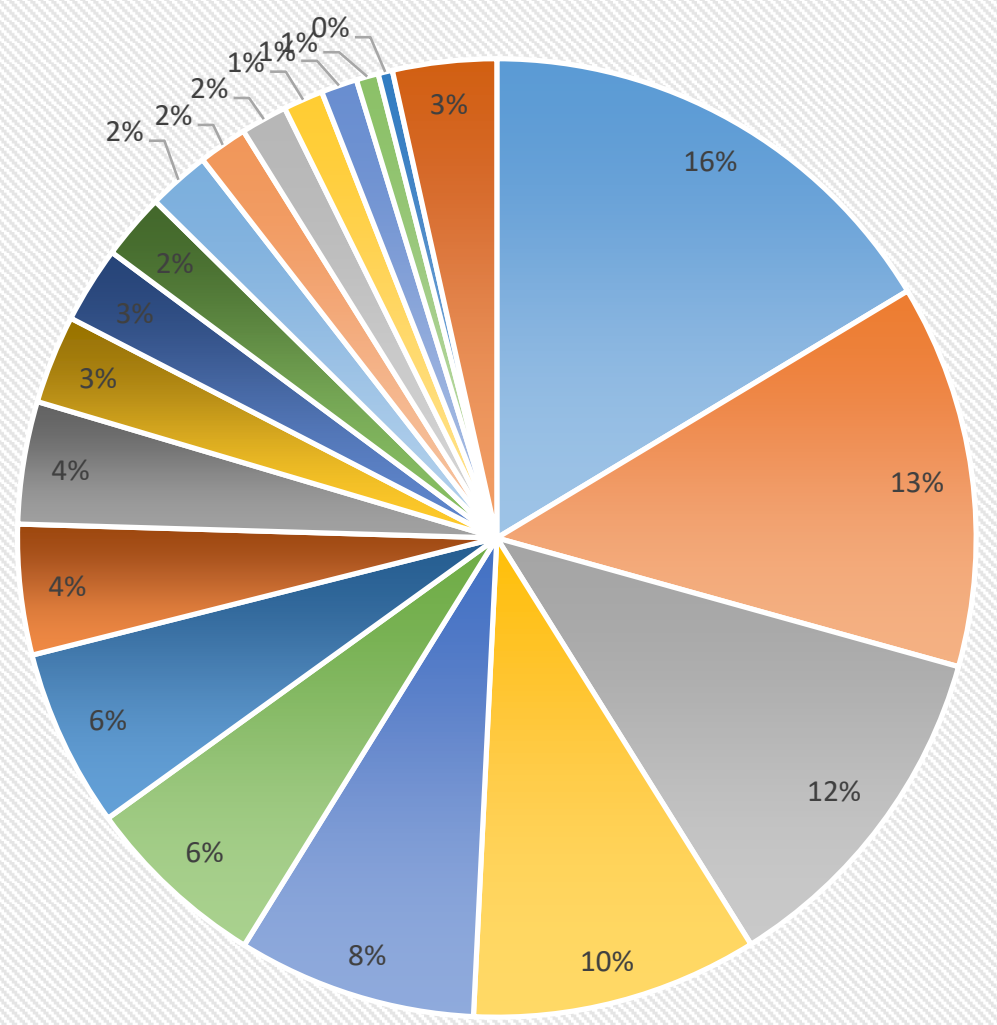

II.1. Transport \& Storage
II.3.b. Energy generation, renewable
sources
IV.1. General Environment Protection

I.4. Water Supply \& Sanitation

- III.1.a. Agriculture

- II.3.f. Energy distribution

- IV.2. Other Multisector

- II.3.a. Energy Policy

- XII. Unallocated / Unspecified

- II.4. Banking \& Financial Services

- II.3.c. Energy generation, nonrenewable sources

- III.1.b. Forestry

- IX. Unallocated / Unspecified

- VIII.3. Disaster Prevention \&

Preparedness

- III.2.a. Industry

Figure 4. Recipient industries of climate aid funds, 2000-2017. 
There are 41 categories of funds donated by climate aid providers to the industry. From figure 4 , it can be found that the top five of the funds donated by climate aid providers from 2000 to 2017 are transport and storage, energy generation (renewable energy), general environment protection, water supply and sanitation and agriculture, which accept 16 percent, 13 percent, 12 percent, 10 percent and 8 percent, respectively, of which about 60 percent of the total amount of money is received. The remaining 36 categories of industries account for only about 40 per cent, indicating that donor countries' preference for climate aid funds is mainly concentrated in these five industries. It can be found that these five industries are not only directly related to climate control, but also related to climate problems, which is enough to show that climate aid providers prefer to invest money in the source of climate-related problems and to achieve a governance effect from the source. In addition, the proportion of funds in these five industries is relatively uniform, basically in about $10 \%$.

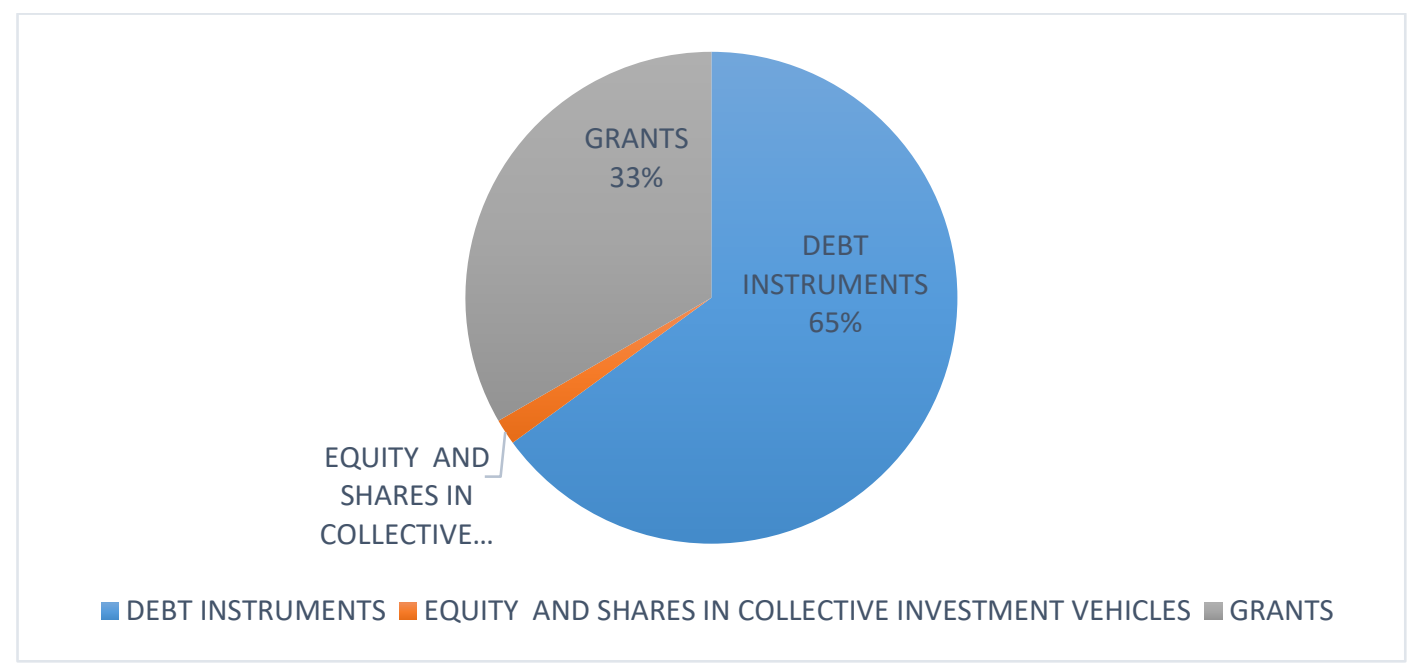

Figure 5. Financial instruments used by donors of climate aid funds, 2000-2017.

As can be seen from figure 5, the most important types of financial instruments for climate aid funds are grants, loans and equity and share in co-investment instruments. Donors to climate aid funds for 2000-2017 are mainly exported in the form of loans, accounting for about 65 percent of the total, while grants account for 33 percent, and only 2 percent of the funds are exported in the form of equity and share in co-investment instruments. Obviously, most of the climate aid funds donated by climate aid donors are not donated directly to other countries for climate governance, but are exported in the form of loans, which illustrates that donors are not unconditionally allocated to donors for climate aid.

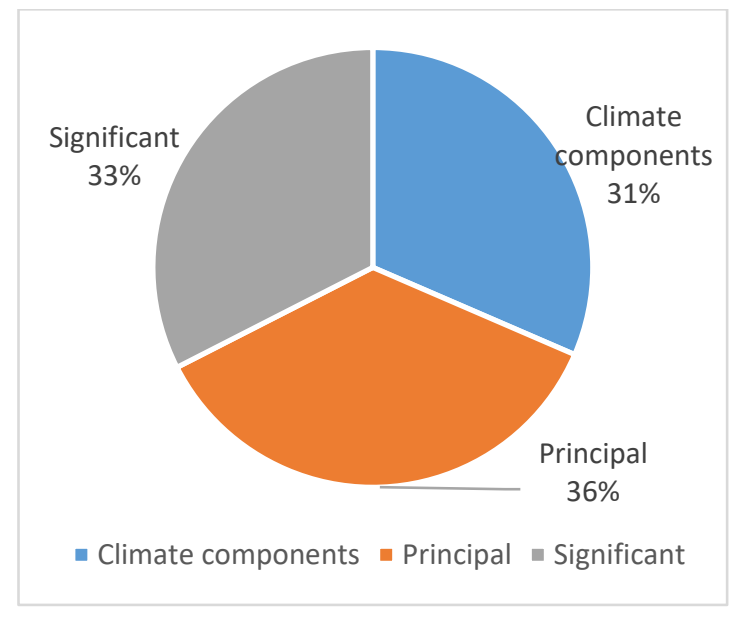

Figure 6. Extent to which climate aid funds target climate change targets, 2000-2017. 


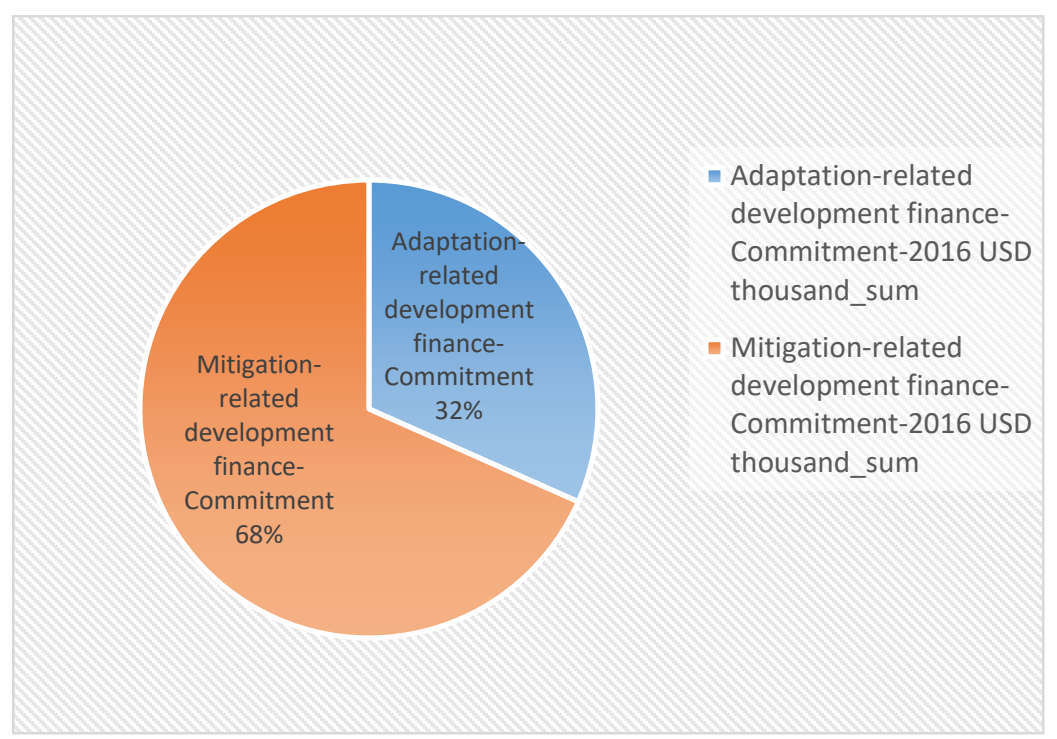

Figure 7. Use of climate aid funds, 2000-2017

As can be seen from figure 6, the preference of climate aid donors for climate change targets for 2000-2017 is not obvious, with the three categories of "principal", "significant" and "climate components" accounting for 36\%, 33\% and 31\%, respectively. The "principal" means that climate aid funds are first aimed at climate change governance, and "significant" means that climate aid funds are important in addressing climate change issues, but are not the first to be used to address climate change issues. It is clear from figure 6 that although the "principal" may be slightly higher than the other two some, but the difference between the three is not significant. But according to OECD, we can categorize the "climate components" as the "principal" category, with the overall proportion of climate aid funds targeting climate change targets at $67 \%$, so the preference of climate aid donors for the extent to which climate aid funds target climate change targets in 2000-2017 is mainly the "principal" category.

As can be seen from figure 7, climate aid funds for climate change mitigation and adaptation accounted for $68 \%$ and $32 \%$ respectively in $2000-2017$, so donors to climate aid funds prefer to be used to mitigate climate change.

\section{2. The reasonableness analysis of climate aid financial preference}

ND-GAIN (The Notre Dame-Global Adaptation Index) is a project of the University of Notre Dame Environmental change Initiative (ND-ECI), which brings together 74 variables, 45 indicators and more than 20 years of data to summarize the vulnerability of 181 countries to climate change. The higher the climate vulnerability index, the greater the risk of climate change, and vice versa. According to the availability of data, this paper selects the vulnerability index of 136 countries, uses the method of ranking the average value of the index, analyzes the 136 countries and their regions and income groups, and then compares with the specific situation of the donation preference from the above analysis, so as to judge the reasonableness of the donor's preference for the recipient.

Table 1. Vulnerability to climate change and donated funds in the top 20 countries in 2000-2017.

\begin{tabular}{cccccc}
\hline $\begin{array}{c}\text { The top 20 countries of } \\
\text { the climate change } \\
\text { vulnerability index } \\
\text { of } \\
\text { donated } \\
\text { funds of } \\
\text { the } \\
\text { country }\end{array}$ & $\begin{array}{c}\text { Ranking of } \\
\text { climate } \\
\text { change } \\
\text { vulnerability } \\
\text { index - } \\
\text { ranking of } \\
\text { donated } \\
\text { funds }\end{array}$ & $\begin{array}{c}\text { Top 20 } \\
\text { recipient } \\
\text { countries }\end{array}$ & $\begin{array}{c}\text { Ranking of } \\
\text { climate } \\
\text { change } \\
\text { vulnerability } \\
\text { index of the } \\
\text { country }\end{array}$ & $\begin{array}{c}\text { ranking of } \\
\text { donated } \\
\text { funds-Ranking } \\
\text { of climate } \\
\text { change } \\
\text { vulnerability } \\
\text { index }\end{array}$ \\
\end{tabular}




\begin{tabular}{|c|c|c|c|c|c|}
\hline Niger & 55 & -54 & India & 47 & 46 \\
\hline Somalia & 88 & -86 & Turkey & 130 & 128 \\
\hline Solomon Islands & 104 & -101 & $\begin{array}{c}\text { China } \\
\text { (People's } \\
\text { Republic of) }\end{array}$ & 103 & 100 \\
\hline $\begin{array}{c}\text { Micronesia, Federated } \\
\text { States of }\end{array}$ & 150 & -146 & Indonesia & 72 & 68 \\
\hline Chad & 95 & -90 & Viet Nam & 56 & 51 \\
\hline Guinea-Bissau & 127 & -121 & Bangladesh & 29 & 23 \\
\hline Sudan & 101 & -94 & Egypt & 87 & 80 \\
\hline Mali & 54 & -46 & Brazil & 120 & 112 \\
\hline Liberia & 84 & -75 & Morocco & 112 & 103 \\
\hline Afghanistan & 35 & -25 & Philippines & 66 & 56 \\
\hline Eritrea & 130 & -119 & Pakistan & 46 & 35 \\
\hline Burkina Faso & 49 & -37 & Ukraine & 127 & 115 \\
\hline $\begin{array}{c}\text { Congo, the Democratic } \\
\text { Republic }\end{array}$ & 133 & -120 & Kenya & 30 & 17 \\
\hline Ethiopia & 18 & -4 & $\begin{array}{l}\text { South of } \\
\text { Sahara, } \\
\text { regional }\end{array}$ & - & - \\
\hline Uganda & 42 & -27 & Anonymised & - & - \\
\hline Benin & 74 & -58 & Mexico & 118 & 102 \\
\hline Madagascar & 70 & -53 & Colombia & 108 & 91 \\
\hline Maldives & 123 & -105 & Ethiopia & 14 & -4 \\
\hline Burundi & 76 & -57 & $\begin{array}{l}\text { Africa, } \\
\text { regional }\end{array}$ & - & - \\
\hline $\begin{array}{l}\text { Central African } \\
\text { Republic }\end{array}$ & 148 & -128 & Peru & 81 & 61 \\
\hline
\end{tabular}

Table 1 selects the top 20 countries of the climate change vulnerability index and the top 20 recipient countries for analysis. In terms of individual countries, the above conclusions show that donors prefer India when providing climate aid funding, followed by Turkey, China, Indonesia and Vietnam. And the five countries that receive the most funding are all out of 30 in terms of climate vulnerability, indicating that these countries are not the most crisis facing the risk of climate change. Overall, of the 17 countries that receive the most donations (three of which do not have relevant data), only three countries rank within 30 in terms of climate vulnerability, while the other 14 countries rank outside 30. Moreover, Niger ranks first in the global climate change vulnerability index and has the worst anti climate change ability in the world. However, it ranks 55th in the list of donated funds, far less than India, which ranks 47th in the list of climate change vulnerability, and Somalia, Solomon Island and the Federated States of Micronesia, which ranked second, third and fourth in climate vulnerability index, rank 60th. Overall, of the 20 most vulnerable countries to climate change, only six 
countries rank within 60 in the list of donated funds, while the other 14 countries rank outside 60 . Compared with the ranking of climate vulnerability and donated funds, only Ethiopia's climate vulnerability and donated funds are roughly matched in the top 20 countries.

Generally speaking, the current preference of donors for countries is not very reasonable. The most vulnerable countries that need climate assistance do not receive the necessary climate assistance funds. Therefore, donor countries should invest more climate assistance funds to the countries with the worst ability to combat climate change.

Table 2. Ranking of regional climate change vulnerability and donated funds in 2000-2017

\begin{tabular}{ccc}
\hline Region & Vulnerability ranking & Ranking of donated funds \\
\hline Oceania & 1 & 5 \\
Africa & 2 & 2 \\
Asia & 3 & 1 \\
America & 4 & 3 \\
Europe & 5 & 4 \\
\hline
\end{tabular}

The regions of 136 countries are listed in Table 2. It can be seen from table 2 that Oceania is the most vulnerable region in the world to resist climate change, but Oceania receives the least climate aid funds, only about 1\%, which shows that the flow of climate aid funds among regions is not reasonable.

Table 3. Ranking of climate change vulnerability and donated funds of income groups in 2000-2017

\begin{tabular}{ccc}
\hline Income groups & Vulnerability ranking & Ranking of donated funds \\
\hline LDCs & 1 & 3 \\
LMICs & 2 & 4 \\
Other LICs & 3 & 1 \\
UMICs & 4 & 2 \\
\hline
\end{tabular}

Similarly, table 3 summarizes the income groups of 136 countries and ranks them. From the perspective of income groups, the most vulnerable income group of global climate change is the least developed countries, followed by other low-income countries. However, from the perspective of donated funds, donor countries prefer low-income countries, accounting for $44 \%$ of the total climate aid funds, followed by low-income countries Middle and high-income countries and regions accounted for $33 \%$, while the least vulnerable least developed countries accounted for only $20 \%$, and other low-income countries accounted for the least, only 3\%. This conclusion fully shows that the preference of climate aid funds of donor countries in 2000-2017 is unreasonable among income groups. Donor countries should invest more climate aid funds in the least developed countries, followed by other low-income countries.

\section{3. Reasonableness analysis of the use of climate aid funds.}

In the above, we have analyzed the Recipient industries of climate aid funds from 2000 to 2017, the purpose and the preference for use, but we do not know whether these industries will make full use of the funds to climate mitigation and adaptation. Therefore, this paper will introduce Rio Marker to analyze the use of funds in recipient industries, in order to explore the reasonableness of the use of climate aid funds. 
The purpose of the Rio Marker is to track the extent to which environmental issues are taken into account in development cooperation projects, rather than quantitative statistics of funds. Therefore, the Rio Marker is based on a set of criteria for the definition and evaluation of projects and activities, that is to say, the core of the statistical data is each grant activity, the main purpose of which is to track various grant flows while avoiding duplicative measurement. The result of marking is to mark items or activities as "principal" (marked as 2), "significant"(marked as 1) and "untargeted" (marked as 0). There are three types of markers: "2", "1" and "0". Only activities or projects that clearly indicate that the underlying purpose or motivation is to mitigate or adapt to climate change can be marked as "2". Those activities or projects that are clearly expressed as belonging to the area of addressing climate change, but whose fundamental purpose or motivation is not to mitigate or adapt to climate change, can only be marked as "1". A project marked "0" means that the activity or project has been verified and is determined not to be aimed at addressing climate change. In short, the Rio marker defines the extent to which each project responds to climate change. Table 4 lists the sectors involved in climate aid funds for 2000-2017 and their possible Rio Marker.

Table 4. The industries involved in climate aid funds and their possible Rio Marker, 2000-2017

\begin{tabular}{|c|c|c|c|}
\hline Recipient industry $^{1}$ & $\begin{array}{c}\text { "Mitigating climate } \\
\text { change" Rio } \\
\text { Marker }^{2}\end{array}$ & $\begin{array}{l}\text { "Adaptating climate } \\
\text { change"Rio Marker" }\end{array}$ & $\begin{array}{l}\text { Proportion of } \\
\text { funds donated } \\
\text { to the industry }\end{array}$ \\
\hline II. 1. Transport \& Storage & $\begin{array}{l}2,1 \text { or } 0 \\
1,2 \text { or } 0\end{array}$ & $\begin{array}{c}0, \text { 1or } 2 \\
\text { 0or } 1\end{array}$ & $16 \%$ \\
\hline $\begin{array}{l}\text { II. 3. b. Energy generation, } \\
\text { renewable sources }\end{array}$ & 2or 1 & 0or 1 & $13 \%$ \\
\hline \multirow{3}{*}{$\begin{array}{l}\text { IV. 1. General Environment } \\
\text { Protection }\end{array}$} & 2 , 1 or 0 & 2 , 1 or 0 & \multirow{3}{*}{$12 \%$} \\
\hline & $\begin{array}{c}\text { 1, 2or } 0 \\
\text { 0or } 1\end{array}$ & $\begin{array}{c}1,2 \text { or } 0 \\
\text { 2or } 1\end{array}$ & \\
\hline & 2,1 or 0 & 2,1 or 0 & \\
\hline $\begin{array}{l}\text { III. 1. a. Water Supply \& } \\
\text { Sanitation }\end{array}$ & 0,1 or 2 & 1,2 or 0 & $10 \%$ \\
\hline I. 4. Agriculture & 0,1 or 2 & 1,2 or 0 & $8 \%$ \\
\hline II. 3. f. Energy distribution & 2,1 or 0 & 0,1 or 2 & $6 \%$ \\
\hline \multirow{3}{*}{ IV. 2. Other Multisector } & 1, 2or 0 & 1,2 or 0 & \multirow{3}{*}{$6 \%$} \\
\hline & 1or 0 & 1, oor 2 & \\
\hline & 0,1 or 2 & 0,1 or 2 & \\
\hline II. 3. a. Energy Policy & 2,1 or 0 & 0, 1or 2 & $4 \%$ \\
\hline XII. Unallocated / Unspecified & n. a & n. a & $4 \%$ \\
\hline $\begin{array}{l}\text { II. 4. Banking \& Financial } \\
\text { Services }\end{array}$ & 0,1 or 2 & 0,1 or 2 & $3 \%$ \\
\hline
\end{tabular}




\begin{tabular}{|c|c|c|c|}
\hline $\begin{array}{l}\text { II. 3. c. Energy generation, } \\
\text { non-renewable sources }\end{array}$ & 0or 1 & 0 & $3 \%$ \\
\hline III. 1. b. Forestry & 2,1 or 0 & 0,1 or 2 & $2 \%$ \\
\hline IX. Unallocated / Unspecified & n. a & n. a & $2 \%$ \\
\hline $\begin{array}{l}\text { VIII. 3. Disaster Prevention \& } \\
\text { Preparedness }\end{array}$ & 0or 1 & 1,2 or 0 & $2 \%$ \\
\hline III. 2. a. Industry & 0,1 or 2 & 0,1 or 2 & $2 \%$ \\
\hline $\begin{array}{l}\text { I. 6. Other Social Infrastructure } \\
\text { \& Services }\end{array}$ & 0, 1or 2 & 0, 1or 2 & $1 \%$ \\
\hline $\begin{array}{l}\text { I. 5. a. Government \& Civil } \\
\text { Society-general }\end{array}$ & $0, \quad 1$ or 2 & 0, 1or 2 & $1 \%$ \\
\hline $\begin{array}{l}\text { VI. 2. Developmental Food } \\
\text { Aid/Food Security aid }\end{array}$ & 0 & 0,1 or 2 & $1 \%$ \\
\hline VIII. 1. Emergency Response & 0or 1 & 0or 1 & $0 \%$ \\
\hline other & n. a & n. a & $3 \%$ \\
\hline
\end{tabular}

Data sources : Annex 18. Rio Markers, The EU guidance by the OECD-DAC committee on Official Development Aid, statistics, https://www. oecd. org/dac/stats/DCD-DAC(2016)3-ADD2-FINAL\%20-ENG. pdf

\footnotetext{
${ }^{1}$ The industry II. 1、IV. 1 and IV. 2. all have different industries under them. There will be different Rio Marker for each sub-industry, but these sub-industries are not specifically covered here, so they are not clearly written.

${ }^{2}$ The Rio Marker of" Climate change mitigation " and "Climate change adaptation" are presented in descending order of probability.
}

The previous analysis found that, in terms of the amount of funds, the top five sectors favoured by climate aid finance- - transport and storage, energy generation (renewable energy), general environment protection, water supply and sanitation, and agriculture- - were $60 \%$ of the total. Therefore, we focus on these five industries. As can be found from Table 5-4, in terms of climate change mitigation, the first place of the Rio Marker in transport and storage, energy generation (renewable energy) and general environment protection is almost 2, followed by 1 , and finally 0 , while the first place of the Rio Marker for water supply and sanitation, agriculture is 0 , followed by 1 , and finally 2. Therefore, on the whole, the preference industry of climate aid funds will be directly or indirectly used to mitigate climate change. In terms of climate change adaptation, transport and storage, energy generation (renewable energy) are the first to be 0 , followed by 1 , and finally 2 , while the Rio Marker for general environment protection, water supply and sanitation, and agriculture are all 1 or 2, and finally 0 . As a result, the preferred industry for climate aid funds is only about half the chance that it will be used to adapt to climate change. With the exception of these five preference industries, it can be found from Table 2 that the rest of the industries are using capital, almost all of which will not be used for climate mitigation or adaptation.

Overall, preference industries for climate aid funds in 2000-2017 spend almost all of their money directly or indirectly on climate mitigation, but less on climate adaptation. The use of climate finance can be divided into two categories: one is to mitigate climate change, the other is to adapt to climate change. Climate finance is used to mitigate climate change to reduce, limit, or store greenhouse gases, while climate change adaptation is used to promote human and ecosystem adaptation to climate change and to reduce current and future risks or vulnerabilities posed by climate change. In addressing climate change, although climate change mitigation and climate change adaptation should complement each other and be indispensable, in the above analysis, we found that the preference 
groups for climate aid funds are mainly least developed and low-and middle-income areas. Most of these regions belong to developing countries, and for developing countries, priority should be given to adaptation to climate change on climate issues. Zheng Dawei mentioned in 2014: Because the current greenhouse gas emission levels in developing countries are very low and are in the historical development stage of industrialization and urbanization, the demand for energy is growing rapidly and reducing emissions is a long-term and arduous task. The adverse impact of climate change on developing countries is more prominent, and adaptation is more realistic and urgent. (Zheng Dawei, 2014). Moreover, since 1990, we have realized that in order to avoid catastrophic disturbances in the global climate, the global average temperature increase cannot exceed the threshold of $2^{\circ} \mathrm{C}$. However, the global average temperature is now $0.8{ }^{\circ} \mathrm{C}$ higher than in the pre-industrial era, and the concentration of carbon dioxide in the atmosphere soared above 400ppm last year (ppm is ppm). Many scientists point out that the more realistic prediction is that global temperatures are likely to rise by 3 to 4 degrees Celsius by the end of the century. Even if we reach the toughest global emission reduction agreement-which is still far away-scientists think it may be too late to stop global warming. And we should be soberly aware of how insignificant our achievements in reducing greenhouse gas emissions have been over the past 29 years, so climate adaptation is the more urgent task right now.

Therefore, on the whole, the use of climate aid funds still lacks a certain reasonableness. So the international community should give full consideration to how to adapt to climate change that has occurred and is about to occur, in particular to improve the ability of developing countries to adapt to climate change and withstand catastrophic climate events. In addition, further attention should be paid to how to adapt to climate change, learn to survive and develop in global climate change, and take effective measures to avoid damage. Mitigating global climate change is a long-term and arduous challenge, and adapting to climate change is a more realistic and urgent task (Liu Yi, Cai Jingjing, 2008).

To sum up, there is a lack of reasonableness in climate aid funds preferences for countries and uses. In the current economic environment, donors should invest more climate aid funds in countries with the worst ability to combat climate change, balance the proportion of climate funds in mitigation and adaptation, and increase donations to climate adaptation.

Authors should discuss the results and hypothesis testing and how they can be interpreted in perspective of previous studies and of the working hypotheses. The findings and their implications should be discussed in the broadest context possible. Future research directions may also be highlighted. Provide an overview of your study limitations i. e. sample size, time-series, methods employed etc.

\section{Conclusions}

This paper abandons the previous research directions of climate finance, such as funds source, responsibility distribution, system design and so on, but studies the preference of climate aid funds, and proves the preference of donor countries when providing climate aid funds by using the relevant climate aid fund data of OECD, and discusses the reasonableness of this preference. Through the analysis, the following conclusions are drawn:

First, overall, donors do have a preference for climate aid. In terms of recipients, donor countries prefer India, Turkey, China, Indonesia and Vietnam in providing climate aid funds. In terms of recipient regions, they prefer Asia, Africa and the Americas. In terms of income groups of the recipients, they prefer low-and middle-income, middle-and high-income and least developed countries and regions. In terms of industries, climate aid providers have preferences for transport and storage, energy generation (renewable energy), general environment protection, water supply and sanitation, and agriculture. In terms of the form of financial instruments, donors mainly prefer loans. In terms of the extent to which climate change goals are targeted, the main preference is "principal", that is, climate aid funds are first aimed at climate change governance. In terms of the use of climate aid funds, donors prefer to donate climate funds to mitigate climate change.

Second, there are some unreasonable problems in the preference of climate aid funds for countries and uses. As far as individual countries are concerned, the most vulnerable countries most 
in need of climate aid do not receive the climate aid funds they deserved. And the preferred industries of climate aid funds invest almost all of them directly or indirectly in climate mitigation when they use the funds, but the direct or indirect investment in climate adaptation is relatively small. Therefore, in the current economic environment, donors should invest more climate aid funds in the countries with the least ability to combat climate change, balance the proportion of climate funds in mitigation and adaptation, and increase donations to climate adaptation. This section is not mandatory but can be added to sum up the topic if results and discussion sections are long or complex.

Acknowledgments: First of all, I would like to thank my supervisor Rong Kang and the teacher Beibei Shi for their help, and secondly, I am very grateful to the Shang Yubing for her help in the process of my writing. She and I finished the writing together. Finally, I would like to thank the National Social Science Fund project "National Climate change negotiation difficulties and China's active participation in the negotiations" for the financial help.

\section{References}

Chen Chen. 2012. UN governance of global climate change. Available online: https://kns.cnki.net/KCMS/detail/detail.aspx?dbcode=CMFD\&dbname=CMFD201301\&filename $=101203848$ 7.nh\&uid=WEEvREcwSIJHSldRa1FhcTdWa2FjcW9zVHkrV1didllzQmZhK3Y0dGlzaz0=\$9A4hF_YAuvQ5o bgVAqNKPCYcEjKensW4IQMovwHtwkF4VYPoHbKxJw!!\&v=MTkyNzJxSkViUEISOGVYMUx1eFITN0Ro MVQzcVRyV00xRnJDVVJMT2VaZVJzRkN2aFZiektWRjI2SExPNOZ0WEU= (accessed on 4 March 2019).

Li Sheng. 2012. Global Climate Governance and China's strategic choice. Available online: https://kns.cnki.net/KCMS/detail/detail.aspx?dbcode=CDFD\&dbname=CDFD1214\&filename=1012358620.n h\&v=Mjk5NThSOGVYMUx1eFITNORoMVQzcVRyV00xRnJDVVJMT2VaZVJyRnl6bFdyL1BWRjI2SExDO UZ0Zk9yNUViUEk= (accessed on 4 March 2019).

Liu Qian. 2016. Climate finance in the era of Paris Agreement: global progress, governance challenges and China's Countermeasures. China Population, Resources and Environment: 12, 14-21. https://doi.org/10.3969/j.issn.1002-2104.2016.12.003

Liu Yi, Cai Jingjing. 2008. Adaptation to Climate change is a realistic Choice: an interview with Luo Yong, Director of the Climate change Center of the China Meteorological Administration. Available online: http://paper.people.com.cn/rmrb/html/2008-07/10/content_56302.htm (accessed on 18 September 2019)

Zheng Dawei. 2014. Adaptation and mitigation should pay equal attention to build a climate - adapted society. Available online: http://www.crd.net.cn/2014-02/27/content_10525195.htm (accessed on 18 September 2019) 